Abdulkerim ÇEVIKER ${ }^{1}$

Hitit University, Sport Sciences Faculty

Hasan Erdem MUMCU ${ }^{2}$

Tokat Gazi Osman Pasa University, Sport Sciences Faculty

Hikmet TURKAY ${ }^{3}$

Gümüshane University, High School of Physical Education and Sport

Osman KUSAN ${ }^{4}$

Gümüshane University, High School of Physical Education and Sport

Ömür F. KARAKULLUKÇU ${ }^{5}$

Ankara Hacı Bayram Veli University, Department of Financial Affairs
Original scientific paper

UDC: 371.72

DOI: $10.5937 /$ istrped2001066C

\title{
EXAMINATION ON PERSONALITY TYPES OF VISUALLY IMPAIRED ELITE ATHLETES
}

\begin{abstract}
The present study aims to examine personalities of visually impaired elite athletes and reveal the effect of sports on personality. The study sample covers 168 visually impaired elite level athletes, 51 of whom were female and 117 of whom were male. The age range of these athletes was $15-25$ years. All visually impaired athletes who participated in the study are competitors in B1 level national teams. The "Big Five Scale" developed John and al., (1991), which was adapted to Turkish by Gencoz and Oncul (2003), was used in the study as the data gathering instrument. The data obtained in the research was transferred into SPSS 22.0 program. Significant differences were found between age groups and personalities of visually impaired athletes in terms of their convergence-peacefulness and personality scale and between score averages of subdimensions in term of sports branch variables.
\end{abstract}

Keywords: Visually Impaired, Sports, Personality Types.

\section{INTRODUCTION}

Disability implies the scope and degree that prevents or restricts participation of an individual in certain activities or tasks which require a normal body function. For example, visual impairment causes activity restriction (disability) and social/professional participation restriction (handicap) (Oyiborhoro, 2005).

Disabled individuals have different lifestyles by the type of the disability they have and the social environment they live in. These lifestyles lead disabled individuals to get involved or be isolated from the society (Cummins and Lau, 2003; Jahoda and Markova, 2004;). The increase in environmental interaction in the social adaptation process of disabled individuals significantly contributes to the improvement of their identity and personality (Fougeyrollas, 1995; Egeberg, 2010). Personality is defined as the psychological characteristics which contribute to permanent and specific emotions, thoughts and behavior patterns of an individual" (Cervone and Pervin, 2010). Internal and external factors which affect the formation of personality are the overall behaviors emerging in certain time periods. 
Personality initially develops with internal and impulses existing in the self (Smith and Canger, 2004; Mumcu and Alay, 2018), and then with motives it is shaped within the existing social environment (Bono and Judge, 2004; Judge et al., 2002). Social environment includes an individual's families, schools, neighbors, relatives, areas of leisure time or sports environment (Franzini et al., 2009).

Sports environment offers many opportunities to enable disabled individuals to display their abilities (Clarke, 1986). Participation in sports activities is a potentially significant factor for psychological wellness in personality development of individuals in addition to psychological and social characteristics (Richter, 1989; Martin, Adams-Mushett and Smith, 1995; Walden, 2007). Moreover, sports teach individuals how to cope with their disability and relieve the status of disability, please them, provide communication and sharing, improve life motivation, and ensure gaining positive personality traits such as honesty, tolerance, cooperation (Brouwer and Ludeke, 1997). Sports open a new door for lives of disabled individuals and enables them to compete. Social life bonds of disabled people who gained athletics character improvements find possibility of gaining an identity and status for themselves in the society (European Commission, 2012). Athlete identity has a significant role in describing a person's personality with many different characteristics (Frederick and Ryan, 1995; Deci and Ryan, 2000). Participation of the disabled in sports implies that they improved their skills of experiencing themselves, loyalty, working devotedly, persevering as well as finding a new social position and identity (Ascione et al., 2018). Disabled individuals engage in various social and sports activities in order to cope with or slightly get rid of the problems caused by their existing situation. Some positive changes occur in their existing personality character at the end of these processes.

Long term research showed positive effects in personality of individuals who regularly exercise and actively participate in sports compared to nonparticipants. There are also previous studies which indicate that participating in and performing sports give rise to some personality changes (Rhodes and Smith, 2006; Rhodes and Pfaeffli, 2012). It is stated that participation in sports creates some differences in personality traits and self-respect of disabled individuals (Lipton, 1970; DePauw, 1986; Atay, 1997; Ferreira and Fox, 2008; Pense et al., 2011; Karakoc et al., 2012). Particularly, physical movement training and exercises starting with rehabilitation process of individuals who become disabled later in life create significant changes in the lifestyle of disabled individuals in time. Research needs to be conducted in order to confirm meaning and significance of sports for disabled athletes by considering the value added by sports to disabled athletes. Therefore, this study aimed to examine personalities of visually impaired elite athletes.

\section{METHOD}

In this chapter, details about the research group, data gathering instruments and analysis of data collected are given.

\section{Research Group}

The research group sample is composed of 168 visually impaired athletes in total including 51 female and 117 male doing sports at an elite level selected in 15-25 age range by the method of purposeful sampling. All visually impaired athletes who participated in the study have been competitors in $\mathrm{B} 1$ level national teams. 


\section{Data Gathering Instruments}

The "Big Five" developed by John, Donahue and Kentle (1991), the version adapted to Turkey and the "Basic Personality Scale for Turkish Culture (TKTKO) developed by Gencoz and Oncul (2003) are used in the study as the data gathering instrument. The scale is composed of 5 subdimensions and 44 items. It includes the subdimensions of Extraversion (8 items), Convergence ( 9 items), Care and Honesty (9 items), Emotional Stability (8 items), OpenMindedness ( 10 items). The scale is 5 -point Likert type scale and evaluated between 1 (strongly agree) and 5 (strongly disagree). The scale was applied by face-to-face interviewing of the athletes who have been involved in national team camps at the stage of data gathering.

\section{Data Analysis}

The data obtained in the research was transferred into SPSS 22.0 program. The conformity of data with normal distribution was evaluated with Kolmogorov Smirnov test. Descriptive statistics analysis (average, standard deviation, frequency and percentage) was held for the definition of characteristics of the research group in data analysis. The correlation between scores acquired by the participants in subdimensions of SGÖ scale in age range (15-25 years old) in terms of TKTKÖ subdimensions was evaluated by using Pearson Product-Moment Correlation Analysis. One-Way Analysis of Variance (ANOVA) was used in order to determine whether TKTKÖ subdimensions differ according to sports branch variables; in case a difference is found, (LSD and Scheffe) Bonferroni Post Hoc test analysis method is used. $t$ Test analysis method was used for independent groups in order to determine the difference in TKTKÖ subdimensions of the athletes according to gender variable.

\section{FINDINGS}

This chapter includes demographic details about students and statistical analysis of data acquired with respect to sub problems of the research.

Table 1. Frequency Distribution with Respect to Demographic Characteristics of Visually Impaired Athletes who participated in the study

\begin{tabular}{|c|c|c|c|c|}
\hline VARIABLES & GROUPS & $\mathbf{N}$ & $\%$ & TOTAL \\
\hline \multirow[t]{2}{*}{ Gender } & Male & 117 & 69.6 & \multirow{2}{*}{168} \\
\hline & Female & 51 & 30.4 & \\
\hline \multirow{3}{*}{$\begin{array}{c}\text { Education } \\
\text { Level }\end{array}$} & Primary School & 25 & 14.9 & \multirow{3}{*}{168} \\
\hline & $\begin{array}{c}\text { Secondary-High } \\
\text { School }\end{array}$ & 114 & 67.9 & \\
\hline & University & 29 & $17 \cdot 3$ & \\
\hline \multirow{7}{*}{ Branch } & Judo & 25 & 14.9 & \multirow{7}{*}{168} \\
\hline & Futsal & 22 & 13.1 & \\
\hline & Athleticism & 18 & 10.7 & \\
\hline & Goalball & 15 & 8.9 & \\
\hline & Swimming & 41 & 24.4 & \\
\hline & Chess & 19 & 11.3 & \\
\hline & Weightlifting & 28 & 16.7 & \\
\hline
\end{tabular}


168 visually impaired athletes in total including $69.6 \%$ male and $30.4 \%$ female participated in the study. $14.9 \%$ of the visually impaired athletes received primary school education, $67.9 \%$ received secondary-high school and $17.3 \%$ received university level education. When we look at the branch allocation of athletes, $14.9 \%$ come from judo, $13.1 \%$ from futsal, $10.7 \%$ from athleticism, $8.9 \%$ from goalball, $24.4 \%$ from swimming, $11.3 \%$ from chess and $16.7 \%$ from weightlifting branches.

Table 2. Correlation Test for the Connection between Personality Traits and Age of Visually Impaired Athletes who participated in the study

\begin{tabular}{|c|c|c|c|c|c|}
\hline & \multicolumn{5}{|l|}{ Age - Personality } \\
\hline & Extraversion & $\begin{array}{c}\text { Convergence- } \\
\text { Peacefulness }\end{array}$ & $\begin{array}{c}\text { Care- } \\
\text { Honesty }\end{array}$ & $\begin{array}{c}\text { Emotional } \\
\text { Stability }\end{array}$ & $\begin{array}{c}\text { Open } \\
\text { Mindedness }\end{array}$ \\
\hline $\begin{array}{c}\text { Pearson } \\
\text { Correlation }\end{array}$ & .068 & .174 & .018 & .048 & -.057 \\
\hline Sig. (2-tailed) & .381 & .024 & .813 & .540 & .461 \\
\hline $\mathrm{N}$ & 168 & 168 & 168 & 168 & 168 \\
\hline
\end{tabular}

There is a statistically significant, same direction and weakly strong correlation between convergence-peacefulness scores among age and personality traits of the visually impaired athletes who participated in the study. [ $\mathrm{r} 2=.174 \mathrm{p}=.024<.05]$. There is no statistically significant correlation between extraversion, care-honesty, emotional stability and open mindedness scores among age and personality traits of the visually impaired athletes who participated in the study. $[\mathrm{r} 1=.068 \mathrm{p}=.381>.05, \mathrm{r} 3=.018 \mathrm{p}=.813>.05, \mathrm{r} 3=.048 \mathrm{p}=.540>.05, \mathrm{r} 5=-$ $.057 \mathrm{p}=.461>.05]$

Table 3. Anova Test for Differentiation of Personality Traits Scores Average of the Visually Impaired Athletes who participated in the study according to Education Level

\begin{tabular}{|c|c|c|c|c|c|c|}
\hline Dimensions & Branch & $\mathbf{N}$ & $\bar{x}$ & S & $\mathbf{F}$ & p \\
\hline \multirow{3}{*}{ Extraversion } & Primary School & 25 & 3.46 & .49 & \multirow{3}{*}{.898} & \multirow{3}{*}{.409} \\
\hline & Secondary School-High School & 114 & 3.51 & .53 & & \\
\hline & University & 29 & 3.63 & .36 & & \\
\hline \multirow{3}{*}{ Convergence-Peacefulness } & Primary School & 25 & 3.28 & .46 & \multirow{3}{*}{1.673} & \multirow{3}{*}{.191} \\
\hline & Secondary School-High School & 114 & 3.34 & .41 & & \\
\hline & University & 29 & 3.47 & .38 & & \\
\hline \multirow{3}{*}{ Care-Honesty } & Primary School & 25 & 3.40 & .34 & \multirow{3}{*}{1.682} & \multirow{3}{*}{.189} \\
\hline & Secondary School-High School & 114 & 3.42 & .48 & & \\
\hline & University & 29 & 3.59 & .47 & & \\
\hline \multirow{3}{*}{ Emotional Stability } & Primary School & 25 & 3.08 & .62 & \multirow{3}{*}{.229} & \multirow{3}{*}{.795} \\
\hline & Secondary School-High School & 114 & 3.06 & .52 & & \\
\hline & University & 29 & 3.13 & .34 & & \\
\hline \multirow{3}{*}{ Open Mindedness } & Primary School & 25 & 3.81 & .50 & \multirow{3}{*}{.899} & \multirow{3}{*}{.409} \\
\hline & Secondary School-High School & 114 & 3.64 & .62 & & \\
\hline & University & 29 & 3.71 & .46 & & \\
\hline
\end{tabular}


Personality traits of the visually impaired athletes who participated in the study do not display a statistically significant difference according to education level variable. $\left[F_{1}(2-165)=.898\right.$ $\mathrm{p}=.409>.05, \quad \mathrm{~F} 2(2-165)=1.673 \quad \mathrm{p}=.191>.05, \quad \mathrm{~F}_{3}(2-165)=1.682 \quad \mathrm{p}=.189>.05, \quad \mathrm{~F}_{4}(2-165)=.229$ $\mathrm{p}=.795>.05, \mathrm{~F} 5(2-165)=.899 \mathrm{p}=.409>.05]$.

Table 4. t Test for Gender Variable Differentiation of Personality Traits Scores Average of the Visually Impaired Athletes Participate in the Study

\begin{tabular}{|c|c|c|c|c|c|c|c|}
\hline Dimensions & Branch & $\mathbf{N}$ & $\overline{\mathbf{x}}$ & $\mathbf{S}$ & sd & $\mathbf{F}$ & $\mathbf{P}$ \\
\hline \multirow{2}{*}{ Extraversion } & Male & 117 & 3.61 & .53 & \multirow{2}{*}{168} & \multirow{2}{*}{.933} & \multirow{2}{*}{.349} \\
\hline & Female & 51 & 3.53 & .46 & & & \\
\hline \multirow{2}{*}{ Convergence-Peacefulness } & Male & 117 & 3.61 & .48 & \multirow{2}{*}{168} & \multirow{2}{*}{.822} & \multirow{2}{*}{.411} \\
\hline & Female & 51 & 3.58 & .45 & & & \\
\hline \multirow{2}{*}{ Care-Honesty } & Male & 117 & 3.51 & .59 & \multirow{2}{*}{168} & \multirow{2}{*}{.439} & \multirow{2}{*}{.661} \\
\hline & Female & 51 & 3.47 & .41 & & & \\
\hline \multirow{2}{*}{ Emotional Stability } & Male & 117 & 2.74 & .50 & \multirow{2}{*}{168} & \multirow{2}{*}{.833} & \multirow{2}{*}{.407} \\
\hline & Female & 51 & 2.82 & .47 & & & \\
\hline \multirow{2}{*}{ Open Mindedness } & Male & 117 & 3.63 & .51 & \multirow{2}{*}{168} & \multirow{2}{*}{.998} & \multirow{2}{*}{.313} \\
\hline & Female & 51 & 3.56 & .68 & & & \\
\hline
\end{tabular}

Any statistically significant difference is not seen in personality traits scores average of the visually impaired athletes who participated in the study according to gender variable. [ $\mathrm{t} 1(168)=$ $.933 \mathrm{p}=.349>.05, \mathrm{t} 2(168)=.822 \mathrm{p}=.411>.05, \quad \mathrm{t} 3(168)=.439 \mathrm{p}=.661>.05, \quad \mathrm{t} 4(168)=-.833$ $\mathrm{p}=.407>.05, \mathrm{t} 5(168)=.998 \mathrm{p}=.313>.05]$.

Table 5. Anova Test for Branch Variable Differentiation of Personality Traits Scores Average of the Visually Impaired Athletes who participated in the study for Branch Differentiation

\begin{tabular}{|c|c|c|c|c|c|c|c|c|c|}
\hline & Dimensions & \multicolumn{2}{|c|}{ Sports Branch } & $\mathbf{N}$ & $\bar{x}$ & $S$ & $\mathbf{F}$ & $\mathrm{p}$ & Different Groups \\
\hline \multirow{20}{*}{ 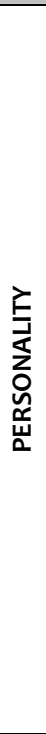 } & \multirow{7}{*}{ Extraversion } & 1) & Judo & 25 & 5.15 & 1.25 & \multirow{7}{*}{7.393} & \multirow{7}{*}{$.000^{x}$} & \multirow{7}{*}{$\begin{array}{l}1-6 \\
1-7 \\
2-6 \\
2-7 \\
4-6 \\
4-7\end{array}$} \\
\hline & & 2) & Futsal & 22 & 4.31 & .83 & & & \\
\hline & & 3) & Athleticism & 18 & 4.49 & .93 & & & \\
\hline & & 4) & Goalball & 15 & 5.41 & .95 & & & \\
\hline & & 5) & Swimming & 41 & $4 \cdot 30$ & .98 & & & \\
\hline & & 6) & Chess & 19 & 3.52 & .86 & & & \\
\hline & & 7) & Weightlifting & 28 & 3.53 & 1,38 & & & \\
\hline & & 1) & Judo & 25 & 5.24 & 1,10 & & & \\
\hline & & 2) & Futsal & 22 & 4.78 &, 72 & & & \\
\hline & & 3) & Athleticism & 18 & 5.41 & 1,28 & & & $1-7$ \\
\hline & Convergence-Peacefulness & 4) & Goalball & 15 & 5.36 & ,71 & 4.541 & $.000^{x}$ & $3-7$ \\
\hline & & 5) & Swimming & 41 & 4.60 & 1,02 & & & $4-7$ \\
\hline & & 6) & Chess & 19 & 5.28 & 1,10 & & & $6-7$ \\
\hline & & 7) & Weightlifting & 28 & 4.33 & 1,11 & & & \\
\hline & Care-Honesty & 1) & Judo & 25 & 5.22 & 1,55 & 1.339 & .191 & - \\
\hline & & 2) & Futsal & 22 & 5.46 & ,68 & & & \\
\hline & & 3) & Athleticism & 18 & 5.49 &, 89 & & & \\
\hline & & 4) & Goalball & 15 & 5.41 &, 93 & & & \\
\hline & & 5) & Swimming & 41 & 5.35 & 1,28 & & & \\
\hline & & 6) & Chess & 19 & 4.44 & ,91 & & & \\
\hline
\end{tabular}




\begin{tabular}{|c|c|c|c|c|c|c|c|c|}
\hline & 7) & Weightlifting & 28 & 5.38 & 1,33 & & & \\
\hline \multirow{7}{*}{ Emotional Stability } & 1) & Judo & 25 & 5.41 & ,103 & \multirow{7}{*}{3.952} & \multirow{7}{*}{.003} & \multirow{7}{*}{$\begin{array}{l}1-7 \\
3-7 \\
4-7\end{array}$} \\
\hline & 2) & Futsal & 22 & 4.98 &, 52 & & & \\
\hline & 3) & Athleticism & 18 & 5.25 &, 79 & & & \\
\hline & 4) & Goalball & 15 & 5.25 & ,61 & & & \\
\hline & 5) & Swimming & 41 & 4.70 &, 88 & & & \\
\hline & 6) & Chess & 19 & 4.39 &, 62 & & & \\
\hline & 7) & Weightlifting & 28 & 4.33 & ,91 & & & \\
\hline \multirow{7}{*}{ Open Mindedness } & & & 25 & 4.99 & 1,52 & \multirow{7}{*}{1.221} & \multirow{7}{*}{1.83} & \multirow{7}{*}{-} \\
\hline & & utsal & 22 & 4.95 &, 79 & & & \\
\hline & & thleticism & 18 & 5.09 &, 84 & & & \\
\hline & & oalball & 15 & $5 \cdot 31$ & ,95 & & & \\
\hline & & vimming & 41 & 5.22 & 1,18 & & & \\
\hline & 6) & ness & 19 & 4.98 &, 98 & & & \\
\hline & 7) & eightlifting & 28 & 5.13 & 1,23 & & & \\
\hline
\end{tabular}

According to Table 4, since the $\mathrm{p}_{-}$values calculated for personality subdimension and extraversion, convergence, peacefulness, emotional stability subdimensions is lower than $a=.05$ value considered as the significance level, there are statistically significant differences in personality scale and subdimension scores average of the visually impaired athletes according to the sports branch variable. Since the $p$ value calculated for care-honesty and open mindedness subdimension is higher than $\alpha=.05$ value, there is no statistically significant difference in introjection subdimension scores average of the visually impaired athletes. [ F1(7$168)=7.393 \mathrm{p}=.000<.05, \mathrm{~F} 2(7-168)=4.541 \mathrm{p}=.000<.05, \mathrm{~F} 3(7-168)=1.339 \mathrm{p}=.191>.05, \mathrm{~F} 4(7-168)=$ $3.952 \mathrm{p}=.002<.05, \mathrm{~F} 5(7-168)=1.221 \mathrm{p}=.183>.05]$.

When we look at the Tukey HSD paired comparison (Scheffe conducted to understand where the difference between the groups results from) test results, paired groups which display difference in Extraversion subdimension scores average are the athletes of judo-chess, judoweightlifting, futsal-chess, futsal-weightlifting, goalball-chess and goalball-weightlifting sports branches. It is in favor of weightlifting and judo sports branches. The paired groups which display difference in convergence-peacefulness subdimension scores average are judoweightlifting, athleticism-weightlifting, goalball-weightlifting and chess-weightlifting and this is in favor of weightlifting athletes. The paired groups which display difference in the emotional stability subdimension scores average are judo-weightlifting, athleticismweightlifting, goalball-weightlifting sports branches and it is in favor of weightlifting and judo. There are no paired groups which display difference in care-honesty and open mindedness sub scale scores average.

\section{DISCUSSION and CONCLUSION}

According to the results of our study conducted to determine personality traits of visually impaired athletes doing sports at the elite level, there are significant differences in terms of age and sports branch variable. No significant results were found according to gender and education level variable as the other variables.

When we look at the age variable, it can be said that a significant correlation is displayed in convergence and peacefulness subdimension. Any correlation between other dimensions and the age variable is not seen. Any age classification was not able to be done because the age of the sample group we created at elite level ranges between 15 and 25 . 
When we look according to the sports branch variable, it is seen that the athletes in judo and goalball sports branches have a greater extraverted structure compared to the athletes in weightlifting and chess branches in the extraversion dimension of personality. Considering that weightlifting and chess sports are the activities mostly done singularly due to the characteristics of these branches, it may be normal that such athletes have a more introverted structure. In the convergence and peacefulness subdimension, it is seen that the athletes in judo, athleticism, goalball and chess sports branches are more convergent and peaceful compare to the athletes practicing in the weightlifting branch. In the emotional stability subdimension as a personality dimension, the athletes in judo, athleticism and goalball sports branches are more stable emotionally compared to the athletes in weightlifting sports. It is seen that the visually impaired athletes who participated in the study had in general emotionally stable, adaptable and convergent personal traits. Smith (2013) states that disabled athletes tend to have an extraverted and socialized structure in his research. Martin et al. (2011) states in the study conducted on Paralympic basketball team members that the team members have positive state of mind and personality traits. These conclusions in the literature also support the study we conducted.

The athletes engaging in the weightlifting branch had lower scores in emotional stability, convergence and extraversion dimensions compare to other athletes in our study. In a study held on personality traits of non-disabled weightlifting athletes, it is stated that the extraversion characteristics of the athletes are greater than introversion characteristics contrary to our study (Ulucan and Bahadir, 2011). We can say according to these results that the weightlifting that is an individually difficult workout and training style have some influences of personality traits depending on disability status. It is seen in the study done by Karakoc et al. (2012) that hearing-impaired judo athletes have a high degree of self-respect. The reason for this has been specified as the fact that judo is a challenging and individual sports is effective in enabling the athletes reaching to high values in self-respect. If we start from there, it can be said that the sports branch being engaged may cause some changes in personality and self-structure for disabled athletes. James and Johnson (1983) stated that the athletes doing individual sports are persons who like to work out alone, want to improve their skills alone, they are more nervous and angrier, self-confident, egocentric and giving sudden reactions (Tazegul, 2012).

The conclusions in our study support the previous studies held on personality traits of athletes (Egan and Stelmack, 2003; Hughes et al., 2003; Cervone and Pervin, 2010; Rhea and Martin, 2010). Moreover, it is stated in a research held on disabled individuals doing and not doing sports in the literature that no difference was found between their personality traits (Hayes, 1996).

In conclusion, it is seen that personalities of visually impaired athletes differ according to the sports branch variable. However, no difference was found between disabled and non-disabled athletes in many studies in the literature including the studies held on personality traits of both groups. Besides this, it is seen that the variables of sports branch being engaged in and the period of doing a sports branch have an influence on personality traits. There is a limited number of studies on personality traits of visually impaired athletes. Increasing the number and scale of such studies and gaining them in the literature are so significant to enable us understanding their influence of sports on disabled individuals. 


\section{BIBLIOGRAPHY}

Ascione, A., Belfiore, P. \& Di Palma, D. (2018). Sport As A Psycho-Social Support In Disability Through The Positive Stimulation Of Self-Efficacy And Resilience, Acta Medica Mediterranea, 34, 1517-1520.

Atay, M. (1997). Engelli Bireylerin Benlik Gelisiminde Spor Etkinliklerinin Onemi. Antalya Uluslararasi Engellilerde Spor Sempozyumu Bildiri Kitabi. T.C. Basbakanlik Genclik ve Spor Genel - Mudurlugu Spor Egitim Dairesi Baskanligi Yayinlari. Yayin No: 1. Ankara. s.98.

Bono, J. E., \& Judge, T. A. (2004). Personality and Transformational Leadership: A Metaanalysis, Journal of Applied Psychology, 89(5), 901-910.

Brouwer, J. \& Ludeke W. (1997). Felsefi Acidan Engellilerde Spor. Antalya Uluslararasi Engellilerde Spor Sempozyumu Bildiri Kitabı. T.C. Basbakanlik GSGM Spor Egitim Dairesi Başkanligi. Yayin No:1. 11-17. Ankara.

Cervone, D. \& Pervin, L. A. (2010). Personality: Theory And Research, 11th edn., New York: Wiley.

Clarke, K. S. (1986). Perspectives For The Future Of The Disabled In Sport, Adapted Physical Activity Quarterly, 3(2), 152-155.

Cummins, R. A. \& Lau, A. L. (2003). Community Integration Or Community Exposure? A Review And Discussion In Relation To People With An Intellectual Disability, Journal of Applied Research In Intellectual Disabilities, 16(2), 145-157.

Deci, E. L., \& Ryan, R. M. (2000). The" what" and" why" of goal pursuits: Human needs and the self-determination of behavior, Psychological inquiry, 11(4), 227-268.

DePauw, K. P. (1986). Research On Sport For Athletes With Disabilities, Adapted physical activity quarterly, 3(4), 292-299.

Egan, S. \& Stelmack, R. M. (2003). A personality profile of Mount Everest climbers, Personality and Individual Differences, 34: 1491-1494.

Egeberg, M. (2010). The European Commission. European union politics, 3, 125-40.

Ferreira, P. \& Fox, K. (2008). Physical Self-perceptions and Self- esteem in Male Basketball Players with and without Disability: A Preliminary Analysis Using the Physical Selfperception Profile, European Journal of Adapted PhysicalActivity, 1(1): 35-49.

Franzini, L., Elliott, M. N., Cuccaro, P., Schuster, M., Gilliland, M. J., Grunbaum, J. A., \& Tortolero, S. R. (2009). Influences Of Physical And Social Neighborhood Environments On Children's Physical Activity And Obesity, American journal of public health, 99(2), 271-278.

Frederick, C. M. \& Ryan, R. M. (1995). Self-Determination in Sport: A Review Using Cognitive Evaluation Theory, International Journal of Sport Psychology, 26, 5-23.

Fougeyrollas, P. (1995). Documenting environmental factors for preventing the handicap creation process: Quebec contributions relating to ICIDH and social participation of people with functional differences, Disability and rehabilitation, 17(3-4), 145-153.

Gencoz, T. \& Oncul, O. (2012). Examination of personality characteristics in a Turkish sample: Development of basic personality traits inventory, The Journal of General Psychology, 139(3), 194-216.

Hayes, T. L. (1996). How Do Athletic Status And Disability Status Affect The Five-Factor Model Of Personality? Human Performance, 9, 121-140.

Hughes, S., Case, H.S., Stuempfle, K.J. \& Evans, D. (2003). Personality Profiles Of Iditasport Ultra-Marathon Participants, Journal of Applied Sport Psychology, 15: 256-261.

Jahoda, A. \& Markova, I. (2004). Coping With Social Stigma: People With Intellectual Disabilities Moving From Institutions And Family Home, Journal Of Intellectual Disability Research, 48(8), 719-729. 
Johnson, J. W. (Ed.). (1983). The book of American Negro poetry (Vol. 43). Houghton Mifflin Harcourt.

Judge, T. A., Bono, J. E., Ilies, R. \& Gerhardt, M. W. (2002). Personality And Leadership: A Qualitative And Quantitative Review, Journal Of Applied Psychology, 87(4), 765-780.

John, O. P., Donahue, E. M., \& Kentle, R. L. (1991). The Big Five Inventory-Versions $4 a$ and 54. Berkeley, CA: University of California,Berkeley, Institute of Personality and Social Research.

Karakoc, O., Coban, B. \& Konar, N. (2012). Isitme Engelli Milli Sporculari ile Spor Yapmayan Engellilerin Benlik Saygisi Duzeylerinin Karsilastirilmasi. Selcuk Universitesi Beden Egitimi ve Spor Bilimleri Dergisi, 14(1), 12-17.

Lipton, B.H. (1970). The Role Of Wheelchair Sports in Rehabilitation, International Rehabilitation Review, 21(2), 25-27.

Martin, J. J., Malone, L. A. \& Hilyer, J. C. (2011). Personality And Mood In Women's Paralympic Basketball Champions, Journal Of Clinical Sport Psychology, 5(3), 197-210.

Martin, J. J., Adams-Mushett, C. \& Smith, K.L. (1995). Athletic Identity And Sport Orientation Of Adolescent Swimmers With Disabilities. Adapted Physical Activity Quarterly, 12(2), 113-123.

Mumcu, H. E. \& Alay Ozgul, S. (2018). Outdoor and indoor sports that require skill executive branches of the personality types of athletes. Uluslararasi Rekreasyon ve Spor Bilimleri Dergisi, 2(1), 19-29.

Oyiborhoro, J. M. (2005). Aural Rehabilitation For People With Disabilities. BRILL.

Pense, M., Demir, H. \& Yaman, F. (2011). Engelli Sporcularda Benlik Algisinin Cesitli Degiskenlere Gore Incelenmesi. I. Uluslararasi Katilimli Engellilerde Beden Egitimi ve Spor Kongresi. Sozel Bildiri, 5- 7 Mayis. Selcuk Universitesi, Konya.

Richter, K. J. (1989). Myths Of Disabled Sports Medicine. Journal of Osteopathic Sports Medicine, 3, 24.

Rhea, D. J. \& Martin, S. (2010). Personality Trait Differences Of Traditional Sport Athletes, Bullriders, And Other Alternative Sport Athletes, International Journal Of Sports Science And Coaching, 5: 75-85.

Rhodes, R. E. \& Smith, N. E. I. (2006). Personality correlates of physical activity: a review and meta-analysis. British journal of sports medicine, 40(12), 958-965.

Rhodes, R. E. \& Pfaeffli, L. A. (2012). Personality and physical activity. The Oxford handbook of exercise psychology, 195-223.

Smith, B. (2013). Sporting spinal cord injuries, social relations, and rehabilitation narratives: An ethnographic creative non-fiction of becoming disabled through sport. Sociology of sport journal, 30(2), 132-152.

Smith, M. A. \& Canger, J. M. (2004). Effects of supervisor "big five" personality on subordinate attitudes, Journal of Business and Psychology, 18(4), 465-481.

Tazegul, U. (2012). Gurescilerin Kisilik Ozellikleri ile Stresle Basa Cikma Tarzlari Arasindaki Iliskinin Belirlenmesi. Yuksek Lisans Tezi, Dumlupinar Universitesi, Saglik Bilimleri Enstitusu. Kutahya.

Ulucan, H. \& Bahadir, Z. (2011). Haltercilerin Kisilik Ozelliklerinin Farkli Degişkenlere Gore Incelenmesi, Journal of Physical Education \& Sports Science/Beden Egitimi ve Spor Bilimleri Dergisi, 5(2).

Walden, K. M. (2007). Stress relief through leisure and complementary and alternative medicine, Illuminare, 8(1), 1-16. 


\section{Biographical notes:}

Dr. Abdulkerim ÇEViKER was born in Ankara in 1984. He completed his primary, secondary and high school education in the Çankaya district of Ankara. In 2009, he graduated from Gazi University School of Physical Education and Sports, Department of Sports Management. Gazi University Institute of Health Sciences successfully completed his Master's Degree in Psychosocial Fields in Sports. He graduated from Ankara University Health Sciences Institute, Department of Physical Education and Sports, in 2017. He worked as a Sports Education Specialist at the Ministry of Youth and Sports for a while. He worked as a coach and referee in many sports branches. He is currently working at Hitit University, Faculty of Sport Sciences.

Dr. Hasan Erdem MUMCU was born in Tokat in 1984. He completed my high school education at Gazi Osman Paşa High School. My undergraduate education is in Gazi University, School of Physical Education and Sports Teaching Department, and in the Gazi University, Institute of Health Sciences Sports Management program; He completed my doctorate education at Dumlupınar University, Institute of Health Sciences, Sports Sciences Department. He works at Tokat Gazi Osman Paşa University. He is a member of the board For All Sports Federation Turkey. He has 2 international books, 5 articles scanned in international indexes, 5 national articles and papers presented in 10 international congresses.

Dr. Hikmet TURKAY was born in Elazığ in 1983. He completed his primary, secondary and high school education in the Keban district of Elazig. In 2010, he graduated from Gazi University School of Physical Education and Sports, Department of Sports Management. After completing his military service, Gazi University Institute of Health Sciences successfully completed his Master's Degree in Psychosocial Fields in Sports. He graduated from Gazi University Health Sciences Institute, Department of Physical Education and Sports, in 2019. He also serves as the Head of Physical Education and Sports School of Gümüşhane University, Department of Physical Education.

Osman KUSAN was born in Samsun in 1980. He completed my high school education at Bafra High School. His undergraduate education is in Gazi University, School of Physical Education and Sports Teaching Department, and in the Gazi University, Institute of Health Sciences Sports Management program; He completed my doctorate education at Dumlupınar University, Institute of Health Sciences, Sports Sciences Department. He works at Gümüşhane University.

Omur Fatih KARAKULLUKCU was born in 1982. He completed his primary and secondary education in Sivas. Karakullukcu, who graduated from Sports Management undergraduate program in 2005, received his doctorate in Sports Sciences in 2009. Karakullukcu, who still continues his business life at Ankara Hacı Bayram Veli University; He started his career as an employee of the Ministry of Youth and Sports in 2007, and continued his career as a lecturer at Kırıkkale University in 2012, and as an advisor to the Ministry of Education between 2013 and 2018. During this period, he briefly served as Los Angeles Educational Attaché. At the same time, the author; Turkey School Sports Federation presidency has continued since 2016. 